\title{
Sodium selenite treatment of vegetable seeds and seedlings and the effect on antioxidant status
}

\author{
Martha Elena de los Santos-Vázquez¹, Adalberto Benavides-Mendoza1, Norma Angélica Ruiz-Torres², \\ Marcelino Cabrera-de la Fuente', Álvaro Morelos-Moreno ${ }^{3 *}$ \\ ${ }^{1}$ Departamento de Horticultura, Universidad Autónoma Agraria Antonio Narro, Buenavista, Saltillo, Coah. C.P. 25315 México, ${ }^{2}$ Centro de \\ Capacitación y Desarrollo de Tecnología de Semillas, Universidad Autónoma Agraria Antonio Narro, Buenavista, Saltillo, Coah. C.P. 25315 \\ México, ${ }^{3}$ CONACYT-Departamento de Horticultura, Universidad Autónoma Agraria Antonio Narro, Buenavista, Saltillo, \\ Coah. C.P. 25315 México
}

\section{A B S T R A C T}

\begin{abstract}
Selenium treatment of plants improves the response to stress and increases their edible contents. The aim of this study was to treat the seeds and seedlings of tomato, lettuce and melon with selenium to verify the effects on growth, antioxidant status, and vitamin $\mathrm{C}$ concentration in the photosynthetic tissues of seedlings. The experiment consisted of two phases: in the first phase, selenium was applied at concentrations of $0,0.1$ and $1 \mathrm{mg} \mathrm{L}^{-1}$ using immersion pre-treatment of the seeds, and fresh and dry weight, leaf area, oxidationreduction potential (ORP) and concentration of vitamin $\mathrm{C}$ were then determined in seedling leaves. In the second phase, selenium was applied to the seedlings at concentrations of 0 and $2 \mathrm{mg} \mathrm{L}^{-1}$ in the nutrient solution and at concentrations of 0 and $5 \mathrm{mg} \mathrm{L}^{-1}$ in a foliar spray at 15 and 30 days after seeding, and the same response variables were measured. Both types of selenium applications were shown to positively affect the antioxidant status and the vitamin C concentration of the three vegetables. Therefore, selenium applied to the seeds positively changes the antioxidant status and the concentration of vitamin $\mathrm{C}$ in the three crops. Additionally, selenium significantly modified melon growth. The application of selenium by irrigation and leaf spraying in seedlings significantly improved the antioxidant status and the vitamin $\mathrm{C}$ concentration in the three species, with only minor changes in biomass and leaf area.
\end{abstract}

Keywords: Antioxidants, Lettuce; Melon; Selenium; Tomato; Vitamin C

\section{INTRODUCTION}

Selenium (Se) is an essential trace element for animals and humans but not for plants; however, it accumulates in different organs of plants, which absorb inorganic Se in the soil and water as selenate $\left(\mathrm{Se}^{6+}\right)$ and selenite $\left(\mathrm{Se}^{4+}\right)$ (Broadley et al., 2006). Selenate is absorbed through a transport process coupled to a $\mathrm{H}^{+}$-ATPase, with the help of a sulfate (Terry et al., 2000) or silicon transporter (Zhao et al., 2010); once absorbed by the plants, maintains the inorganic form (De Souza et al., 1998; Cartes et al., 2006). In contrast, the absorption of selenite occurs in a different way (Terry et al., 2000), through a phosphate transporter (Zhao et al., 2010). Once absorbed, selenite remains in organic form (De Souza et al., 1998; Cartes et al., 2006) and has been shown to be a more efficient inducer of glutathione peroxidase (Cartes et al., 2005). Selenium is thought to be associated with antioxidant metabolism (Lin et al., 2012; Feng et al.,
2013) through its function as a cofactor of selenoenzymes (Combs, 2001); its deficiency could provoke changes in the cellular redox balance.

Se content in soils varies considerably, and its availability in agricultural soils is usually low; therefore, Se is often used in fertilizers for crops (Fordyce, 2013). Several researchers have described Se application to plants (Bittman et al., 2000; Xue et al., 2001; Rayman, 2008; Becvort-Azcurra et al., 2012; Castillo-Godina et al., 2016), observing a positive effect on antioxidant activity, productivity and yield, and biofortification of leaves and fruits. However, negative consequences have also been described in the literature, usually caused by high concentration of selenium. For that reason, it is important to select the most appropriate method to apply selenium and induce antioxidants and other positive responses in plants (Businelli et al., 2015). The application of Se in seeds may be an alternative; however, information

\footnotetext{
*Corresponding author:

Álvaro Morelos-Moreno, CONACYT-Departamento de Horticultura, Universidad Autónoma Agraria Antonio Narro, Buenavista, Saltillo, Coah. C.P. 25315 México. Mobile: 52 8442957614. E-mail: amorelosmo@conacyt.mx
}

Received: 11 March 2016;

Revised: 20 April 2016;

Accepted: 26 April 2016;

Published Online: 01 May 2016 
regarding Se application to seeds (Jisha et al., 2013; Nawaz et al., 2013) and seedlings (Nawaz et al., 2014; Businelli et al., 2015), and its effect on growth and antioxidants is limited. The aim of this study was to apply $\mathrm{Se}$ in the form of $\mathrm{Se}^{4+}$ to seeds and seedlings of tomato (Solanum bycopersicum L.), lettuce (Lactuca sativa L.) and melon (Cucumis melo L.) and study the effects on growth, antioxidant status and the concentration of vitamin $\mathrm{C}$ in the photosynthetic tissues of the seedlings. We hypothesized that the application of $\mathrm{Se}^{4+}$ to both the seeds and seedlings via a nutrient solution and foliar spraying will modify the cellular redox balance, increasing the antioxidant capacity of photosynthetic tissues.

\section{MATERIALS AND METHODS}

This work was carried out at the Antonio Narro Agricultural University in Saltillo, Mexico. Three species were evaluated: tomato cv. Rio Grande, lettuce cv. Great Lakes, and melon cv. Top Mark. The experimental procedure had two phases. In phase 1 , selenium was applied as sodium selenite $\left(\mathrm{Se}^{4+}\right)$ (Sigma-Aldrich, USA) to seeds by dip solutions with concentrations of $0,0.1$ and $1 \mathrm{mg} \mathrm{L}^{-1}$ for absorption times of $8 \mathrm{~h}$ for tomato, $2 \mathrm{~h}$ for lettuce, and $12 \mathrm{~h}$ for melon. Imbibition times were based on the maximum water uptake by the seeds obtained in a preliminary test. Subsequently, seeds treated with $\mathrm{Se}^{4+}$ were planted in polyethylene pots with $1 \mathrm{~kg}$ substrate consisting of peat moss and perlite (70:30 v:v) using a random treatment distribution. In the seedlings, the following variables were determined for six replicates per treatment: fresh and dry biomass of the whole seedlings with an Adventurer Pro analytical balance (Ohaus, Inc., USA); leaf area with a LI-3100C leaf area meter (LICOR, Inc., USA); vitamin $\mathrm{C}$ concentration in the leaves by the titration method (Padayatti et al., 2001); $\mathrm{pH}$ and redox potential (ORP) of fresh extracts of stems and leaves with a HI98185-01 potentiometer (HANNA, Inc., USA) using the technique described by Benavides-Mendoza et al. (2002).
In phase 2, the vegetable seeds of the three species were sown without $\mathrm{Se}^{4+}$ treatment in polyethylene pots with $2 \mathrm{~kg}$ substrate consisting of peat moss and perlite $(70: 30 \mathrm{v}: \mathrm{v})$. After emerging, the seedlings were treated with $\mathrm{Se}^{4+}$ at concentrations of 0 and $2 \mathrm{mg} \mathrm{L}^{-1}$ in the nutrient solution using an irrigation system, which was based on the method of Steiner (Steiner, 1961) with $50 \%$ of the concentration at a $\mathrm{pH}$ of 6.5 from 15 to 30 days after sowing. The seedlings were irrigated with $200 \mathrm{~mL} \mathrm{day}^{-1}$ per plant. The second type of treatment was $\mathrm{Se}^{4+}$ at concentrations of 0 and $5 \mathrm{mg} \mathrm{L}^{-1}$ by foliar spray at 15 and 30 days after sowing with no surfactant or adherent. The same analyses were performed 30 days after sowing. The statistical design was randomized, with complete blocks receiving treatments with six replicates. Data analysis was performed with the R program (R Core Team, 2015).

\section{RESULTS}

\section{Leaf area, fresh weight and dry weight}

The seed treatment with $\mathrm{Se}^{4+}$ resulted in no significant differences in leaf area, fresh weight, and dry weight in tomato and lettuce. For melon, the leaf area was significantly different in the group that received $1 \mathrm{mg} \mathrm{L}^{-1}$ compared to the control treatment. Fresh weight showed significant differences in the three concentrations. Dry weight was significantly increased by treatment with $0.1 \mathrm{mg} \mathrm{L}^{-1}$, but by increasing the concentration to $1 \mathrm{mg} \mathrm{L}^{-1}$, there were no significant differences (Table 1). Following $\mathrm{Se}^{4+}$ application to the seedlings via the nutrient solution and foliar spray, the three vegetables showed no significant differences between concentrations and types of application except for the dry weight of the tomato.

\section{Oxidation-reduction potential (ORP)}

After the $\mathrm{Se}^{4+}$ application to the seeds, the ORP values showed significant differences with a concentration of $1 \mathrm{mg} \mathrm{L}^{-1}$ in

Table 1: Average values of leaf area and biomass of tomato, lettuce and melon seedlings for Se ${ }^{4+}$ treatment of the seeds and seedlings by nutrient solution and foliar spray

\begin{tabular}{|c|c|c|c|c|c|c|c|c|c|}
\hline \multirow{3}{*}{$\begin{array}{l}\text { Treatment } \\
\mathrm{mg} \mathrm{L}^{-1}\end{array}$} & \multicolumn{3}{|c|}{ Tomato } & \multicolumn{3}{|c|}{ Lettuce } & \multicolumn{3}{|c|}{ Melon } \\
\hline & LA & FW & DW & LA & FW & DW & LA & FW & DW \\
\hline & $\mathrm{cm}^{2}$ & g & g & $\mathrm{cm}^{2}$ & g & g & $\mathrm{cm}^{2}$ & g & g \\
\hline \multicolumn{10}{|c|}{$\mathrm{Se}^{4+}$ applied to seeds } \\
\hline 0 & $571.47 a$ & $57.56 a$ & $7.88 a$ & $1884.3 a$ & $109.22 a$ & $10.35 a$ & $854.07 b$ & $46.88 c$ & $5.18 b$ \\
\hline 0.1 & $512.54 a$ & $49.40 \mathrm{a}$ & $6.91 a$ & $1686.8 \mathrm{a}$ & $120.78 a$ & $11.26 \mathrm{a}$ & $877.95 a b$ & $65.43 a$ & $8.12 a$ \\
\hline 1.0 & $587.62 a$ & $58.10 \mathrm{a}$ & $8.25 a$ & $1772.1 \mathrm{a}$ & $101.59 a$ & $8.51 \mathrm{a}$ & $922.56 a$ & $57.62 b$ & $8.97 a$ \\
\hline \multicolumn{10}{|c|}{$\mathrm{Se}^{4+}$ applied to seedlings in the nutrient solution } \\
\hline 0 & $2559.0 a$ & $66.12 \mathrm{a}$ & $7.45 a$ & $2693.4 a$ & $221.28 \mathrm{a}$ & $14.43 a$ & $3580.4 a$ & $234.44 a$ & $31.33 a$ \\
\hline 2 & $2560.5 a$ & $58.69 a$ & $6.34 b$ & $3386.1 \mathrm{a}$ & $246.87 a$ & $17.11 \mathrm{a}$ & $3150.9 a$ & $205.37 a$ & $38.50 \mathrm{a}$ \\
\hline \multicolumn{10}{|c|}{$\mathrm{Se}^{4+}$ applied to seedlings by foliar spray } \\
\hline 0 & $2760.0 a$ & $69.09 a$ & $7.22 a$ & $3224.5 a$ & $252.68 a$ & $16.75 a$ & $2888.9 a$ & $213.30 a$ & $37.42 \mathrm{a}$ \\
\hline 5 & $2460.2 a$ & $60.05 a$ & $7.55 a$ & $2904.4 a$ & $217.99 a$ & $14.45 a$ & $3223.1 \mathrm{a}$ & 229.26a & $39.31 a$ \\
\hline
\end{tabular}

$\mathrm{LA}=\mathrm{Leaf}$ area, $\mathrm{FW}=$ Fresh weight, $\mathrm{DW}=$ Dry weight. Values followed by identical letters in columns showed no statistically significant differences among treatments according to Tukey's test $(P>0.05)$ 
tomato and 0.1 and $1 \mathrm{mg} \mathrm{L}^{-1}$ in lettuce and melon compared to the corresponding control treatments. By increasing the $\mathrm{Se}^{4+}$ dose from 0.1 to $1 \mathrm{mg} \mathrm{L}^{-1}$, the ORP increased $18.6 \%$ in lettuce and decreased 35.9 and $21.2 \%$ in tomato and melon, respectively. The ORP values of the three vegetables showed significant differences following the $\mathrm{Se}^{4+}$ application to the seedlings in both the $2 \mathrm{mg} \mathrm{L}^{-1}$ nutrient solution and the $5 \mathrm{mg}$ $\mathrm{L}^{-1}$ foliar spray treatments compared to the control treatments, with improvements in antioxidant capacity, except for the foliar spray application to tomato (Fig. 1).

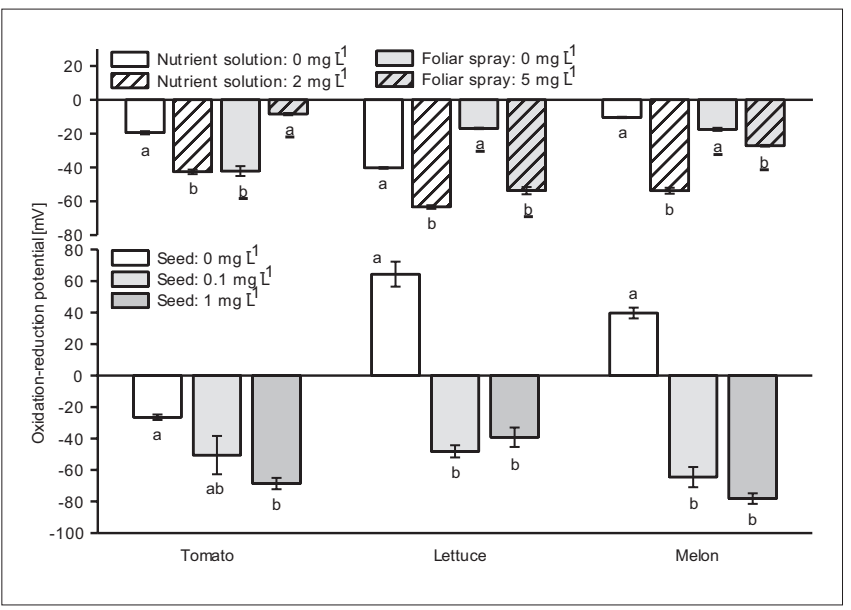

Fig 1. Average values and standard error of the oxidation-reduction potential from fresh extracts of tomato, lettuce and melon seedlings for $\mathrm{Se}^{4+}$ treatment of the seeds and seedlings by nutrient solution and foliar spray. Identical letters indicate no statistically significant differences among treatments and species using Tukey's test $(P>0.05)$.

\section{Vitamin C}

Vitamin C concentration showed significant differences only in tomato following $\mathrm{Se}^{4+}$ application to the seed. The $0.1 \mathrm{mg} \mathrm{L}^{-1}$ dose of $\mathrm{Se}^{4+}$ applied to the seed increased the vitamin $\mathrm{C}$ concentration in the tomato by $44.9 \%$ (Fig. 2 ).

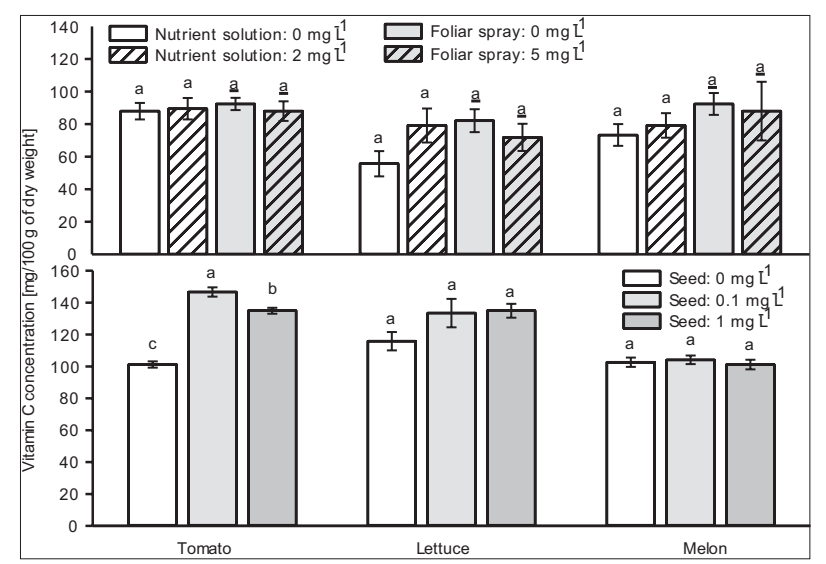

Fig 2. Average values and standard error of the vitamin $C$ concentrations in the leaves of tomato, lettuce and melon seedlings for $\mathrm{Se}^{4+}$ treatment of the seeds and seedlings by nutrient solution and foliar spray. Identical letters indicate no statistically significant differences among treatments and species using Tukey's test $(P>0.05)$.
$\mathrm{Se}^{4+}$ treatment of the seeds had a positive effect on the concentration of vitamin $\mathrm{C}$ and the antioxidant capacity in the tomato, lettuce, and melon seedlings. The ORP showed a tendency to decrease, and the vitamin $\mathrm{C}$ concentration showed a tendency to increase. The adjusted linear regression models for the relationships between these variables are presented in Table 2. The regression coefficient was significant $(\mathrm{P} \leq 0.05)$, but because of the wide dispersion of the data, the $\mathrm{R}^{2}$ value was very low. However, when $\mathrm{Se}^{4+}$ was applied to the the seedlings in the nutrient solution and foliar spray, the ORP and vitamin $C$ values were proportional, which indicated a different response than that observed with application of $\mathrm{Se}^{4+}$ to the seeds (Table 2).

Table 2: Relationship among oxidation-reduction potential and the vitamin $C$ concentration in the fresh leaf extracts of tomato, lettuce and melon seedlings for different $\mathrm{Se}^{4+}$ application methods

\begin{tabular}{lcc}
$\begin{array}{l}\text { Se }{ }^{4+} \text { application } \\
\text { method }\end{array}$ & \multicolumn{1}{c}{ Regression model } & $\begin{array}{c}\text { Coefficient of } \\
\text { determination }\end{array}$ \\
\hline Seed & Vit $\mathrm{C}=-0.0854^{*} \mathrm{ORP}+116.8769$ & $\mathrm{R}^{2}=0.0448$ \\
Nutrient solution & Vit $\mathrm{C}=0.0161^{*} \mathrm{ORP}+78.1051$ & $\mathrm{R}^{2}=0.0002$ \\
Foliar spray & Vit $\mathrm{C}=0.2329^{*} \mathrm{ORP}+92.2322$ & $\mathrm{R}^{2}=0.0280$ \\
\hline
\end{tabular}

\section{$\mathrm{pH}$}

The $\mathrm{pH}$ values of the fresh leaf extract in tomato showed no statistically significant differences after $\mathrm{Se}^{4+}$ applications. Significant differences in $\mathrm{pH}$ values were observed in lettuce with the $\mathrm{Se}^{4+}$ application to the seeds, in the melon with $\mathrm{Se}^{4+}$ application in the nutrient solution, and in lettuce and melon for $\mathrm{Se}^{4+}$ application via foliar spray. The $\mathrm{pH}$ values of the vegetable seedlings increased between 0.3 and $0.7 \%$ when $\mathrm{Se}$ was applied via the nutrient solution and decreased between 1.7 and 2.5\% when Se was applied via foliar spray (Fig. 3).

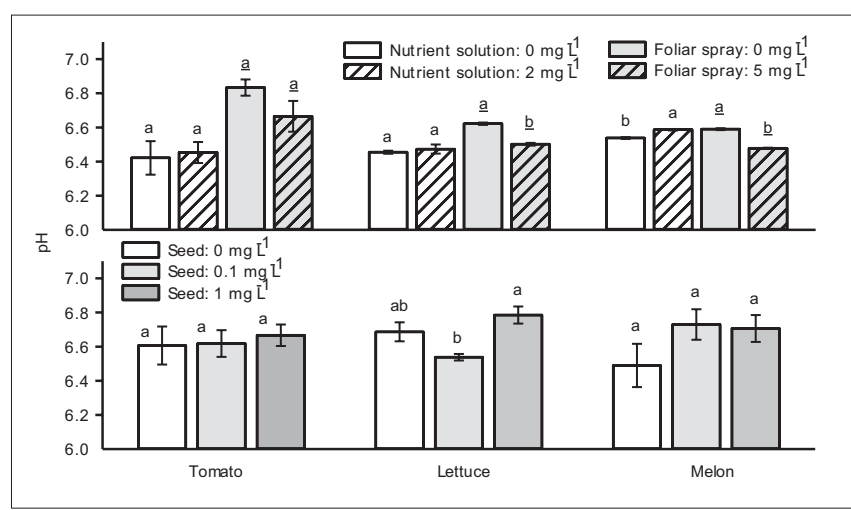

Fig 3. Average values and standard error of the $\mathrm{pH}$ values of the fresh leaf extract of tomato, lettuce and melon seedlings, for $\mathrm{Se}^{4+}$ treatment of the seeds and seedlings by nutrient solution and foliar spray. Identical letters indicate no statistically significant differences among treatments and species using Tukey's test $(P>0.05)$.

\section{DISCUSSION}

Becvort-Azcurra et al. (2012) reported that Se applications up to $2.5 \mathrm{mg} \mathrm{L}^{-1}$ in fertilizer solution in the soil and perlite 
substrate for tomato had positive effects on plant growth. Xue et al. (2001) also reported that Se concentrations up to $0.1 \mathrm{mg} \mathrm{kg}^{-1}$ in the soil had positive effects on growth in lettuce. In the case of lettuce, it was reported that $1 \mathrm{mg} \mathrm{kg}^{-1}$ of Se was toxic (Xue et al., 2001). In this study, $\mathrm{Se}^{4+}$ application at $1 \mathrm{mg} \mathrm{L}^{-1}$ to the seeds caused no toxicity (Table 1).

The quantities of $\mathrm{Se}^{4+}$ applied in the nutrient solution and with the foliar spray are high but did not exceed those used by Becvort-Azcurra et al. (2012) and Xue et al. (2001), who, along with Ramos et al. (2010), reported a positive effect of Se on vegetable growth (Table 1).

$\mathrm{Se}^{4+}$ treatment in tomato, lettuce and melon improved the antioxidant capacity (Fig. 1), which is reflected by the reduction in the oxidation-reduction potential (ORP) of the fresh extract from the seedlings (Benavides-Mendoza et al., 2002). ORP values indicate the antioxidant capacity, i.e., the ability of the system under analysis to donate electrons compared to hydrogen electrode (BenavidesMendoza et al., 2002); lower ORP values indicate a greater capacity to donate electrons and act as an antioxidant. In lettuce plants, a low ORP in leaf extracts was linked to increased catalase activity (López-Gutiérrez et al., 2015). In this study, the relationship between ORP and vitamin C concentration was significant but showed variability. An association between ORP and vitamin $\mathrm{C}$ is expected, as the ORP is an indicator of the concentration of antioxidant molecules present in plant cells. However, there was a very low $\mathrm{R}^{2}$ value possibly due to other antioxidants that also contribute to the ORP. The ability to donate electrons to the system is higher when the ORP value is lower. The increase in electron delivery may be related to increased activity of antioxidant enzymes, which was found in the presence of specific Se concentrations (Freeman et al., 2010).

The increase in the antioxidant capacity of the seedlings treated with $\mathrm{Se}^{4+}$ supports the use of this element in crop fertilizer. $\mathrm{Se}^{4+}$ treatments of $0.1,2$ and $5 \mathrm{mg} \mathrm{L}^{-1}$ in the seeds and seedlings by nutrient solution and foliar spray, respectively, showed the better performances to increase the antioxidant capacity (Fig. 1).

Antioxidant capacity and vitamin $\mathrm{C}$ concentration showed proportional increases in response to $\mathrm{Se}^{4+}$ application, except for the foliar spray method in lettuce and melon, where the vitamin $\mathrm{C}$ concentration decreased (Figs. 1 and 2, Table 2). The increase in vitamin $\mathrm{C}$ concentration following $\mathrm{Se}^{4+}$ treatment of the seeds indicates that this method may induce stress tolerance in seedlings (Fig. 2).

The positive effects of $\mathrm{Se}^{4+}$ on plant antioxidants (Figs. 1 and 2) was described by other authors, such as Xu et al.
(2003), Hajiboland and Amjad (2007), Ramos et al. (2010) and Becvort-Azcurra et al. (2012) (Fig. 1). In Stanleya pinnata, a selenium hyperaccumulator plant, Freeman et al. (2010) found that the presence of $\mathrm{Se}$ in the form of $\mathrm{Se}^{6+}$ induced higher vitamin $\mathrm{C}$ contents, possibly as a response to oxidative stress caused by the high concentration of Se.

In this study, the Se concentrations applied as $\mathrm{Se}^{4+}$ were not high, and the presence of this nutrient in low concentrations in both the seeds and seedlings had an antioxidant effect and increased the vitamin $\mathrm{C}$ concentration in plant cells (Djanaguiraman et al., 2010) (Figs. 1 and 2). Similarly, Ramírez et al. (2010) found that other tolerance-inducing compounds and even environmental factors (Munné-Bosch et al., 2013) could increase the vitamin $C$ concentration (Fig. 2). The $\mathrm{pH}$ of the fresh leaf extracts of the three crops showed normal values between 6.4 and 6.8. It was expected that the $\mathrm{pH}$ would be related to the ORP or vitamin $\mathrm{C}$, considering that the $\mathrm{pH}$ is an indicator of protonation and the activity of molecules (Fig. 3). The results, however, indicated no association between the variables. In other studies, the $\mathrm{pH}$ has been linked to the quality of the storage organs (Benavides-Mendoza et al., 2002).

\section{CONCLUSIONS}

$\mathrm{Se}^{4+}$ application in tomato, lettuce and melon, both in the seeds and seedlings via nutrient solution and foliar spray, improved the antioxidant status and vitamin $\mathrm{C}$ concentration and also increased the leaf area and the fresh and dry weights of the seedlings in some cases. Based on these results, $\mathrm{Se}^{4+}$ applications of $1 \mathrm{mg} \mathrm{L}^{-1}$ in tomato seeds and $0.1 \mathrm{mg} \mathrm{L}^{-1}$ in melon seeds are recommended to increase the leaf area and the fresh and dry weight, which can improve fruit yields. To improve the antioxidant capacity and vitamin $C$ concentration, $\mathrm{Se}^{4+}$ applications of $0.1 \mathrm{mg} \mathrm{L}^{-1}$ in the seeds for all three vegetables are recommended. Increased doses could possibly be used in vegetables, except for lettuce, and in the seedlings at $2 \mathrm{mg} \mathrm{L}^{-1}$ in a nutrient solution for the three vegetables and at $5 \mathrm{mg} \mathrm{L}^{-1}$ by foliar spray in lettuce and melon.

\section{Authors contributions}

All authors contributed extensively to the work presented in this paper. MESV performed the field experimentation, data analysis, and the first draft of the manuscript; $A B M$ planned and designed the study conceptualization, data curation, results interpretation, and critically revised the paper; NART participated in the laboratory experimentation; MCF participated in the field experimentation; AMM participated in data curation, data interpretation, analytical tools and manuscript writing. Also all five authors were involved in the review and editing the final manuscript.

Emir. J. Food Agric • Vol 28 • Issue 8 • 2016 


\section{REFERENCES}

Becvort-Azcurra, A., L. O. Fuentes-Lara, A. BenavidesMendoza, H. Ramírez, V. Robledo-Torres and M. N. RodríguezMendoza. 2012. Application of selenium in tomato: effects on plant growth, productivity and fruit antioxidant status. Terra Latinoamericana. 30: 291-301.

Benavides-Mendoza, A., H. Ramírez, V. Robledo-Torres, E. Cornejo-Oviedo and R. K. Maiti. 2002. Productivity, $\mathrm{CO}_{2}$ assimilation, and mineral tissue concentrations in onion plants under colored plastic films. Crop Res. 24: 26-39.

Bittman, S., W. T. Buckley, K. Zaychuk and E. A. P. Brown. 2000. Seed coating for enhancing the level of selenium in crops. The Minister of Agriculture and Agri-Food Canada, U.S. Patent 6058649 A.

Broadley, M. R., P. J. White, R. J. Bryson, M. C. Meacham, H. C. Bowen, S. E. Johnson, M. J. Hawkesford, S. P. McGrath, F. J. Zhao, N. Breward, M. Harriman and M. Tucker. 2006. Biofortification of UK food crops with selenium. Proc. Nutr. Soc. 65: 169-181.

Businelli, D., R. D'Amato, A. Onofri, E. Tedeschini and F. Tei. 2015. Seenrichment of cucumber (Cucumis sativus L.), lettuce (Lactuca sativa L.) and tomato (Solanum lycopersicum L. Karst) through fortification in pre-transplanting. Sci. Hortic. 197: 697-704.

Cartes, P., L. Gianfreda and M. L. Mora. 2005. Uptake of selenium and its antioxidant activity in ryegrass when applied as selenate and selenite forms. Plant Soil. 276: 359-367.

Cartes, P., C. Shene and M. L. Mora. 2006. Selenium distribution in ryegrass and its antioxidant role as affected by sulfur fertilization. Plant Soil. 285: 187-195.

Castillo-Godina, R. G., R. Foroughbakhch-Pournavab and A. Benavides-Mendoza. 2016. Effect of selenium on elemental concentration and antioxidant enzymatic activity of tomato plants. J. Agric. Sci. Technol. 18: 233-244.

Combs, G. F. Jr. 2001. Selenium in global food systems. Br. J. Nutr. 85: 517-547.

De Souza, M. P., E. A. H. Pilon-Smits, C. M. Lytle, S. Hwang, J. Tai, T. S. Honma, L. Yeh and N. Terry. 1998. Rate-limiting steps in selenium assimilation and volatilization by Indian mustard. Plant Physiol. 117: 1487-1494.

Djanaguiraman, M., P. V. V. Prasad and M. Seppanen. 2010. Selenium protects sorghum leaves from oxidative damage under hightemperature stress by enhancing antioxidant defense system. Plant Physiol. Biochem. 48(12): 999-1007.

Feng, R., C. Wei and S. Tu. 2013. The roles of selenium in protecting plants against abiotic stresses. Environ. Exp. Bot. 87: 58-68.

Fordyce, F. M. 2013. Selenium deficiency and toxicity in the environment. In: Selinus, O., B. Alloway, J. Centeno, R. Finkelman, R. Fuge, U. Lindh and P. Smedley (Eds.), Essentials of Medical Geology, Elsevier, Amsterdam, The Netherlands. Pp. 375-416.

Freeman, J. L., M. Tamaoki, C. Stushnoff, C. F. Quinn, J. J. Cappa, J. Devonshire, S. C. Fakra, M. A. Marcus, S. P. McGrath, D. Van Hoewyk and E. A. H. Pilon-Smits. 2010. Molecular mechanisms of selenium tolerance and hyper accumulation in Stanleya pinnata. Plant Physiol. 153: 1630-1652.

Hajiboland, R. and L. Amjad. 2007. Does antioxidant capacity of leaves play a role in growth response to selenium at different sulfur nutritional status? Plant Soil Environ. 53: 207-215.

Jisha, K. C., K. Vijayakumari and J. T. Puthur. 2013. Seed priming for abiotic stress tolerance: An overview. Acta Physiol. Plant. 35(5): 1381-1396.

Lin, L., W. Zhou, H. Dai, F. Cao, G. Zhang and F. Wu. 2012. Selenium reduces cadmium uptake and mitigates cadmium toxicity in rice. J. Hazard. Mater. 235-236: 343-351.

López-Gutiérrez, M. L., A. Benavides-Mendoza, H. OrtegaOrtíz, L. A. Valdez-Aguilar, M. Cabrera-De la Fuente, A. Sandoval-Rangel. 2015. Selenium and its effect on antioxidant status and mineral composition of lettuce. Rev. Mex. Cien. Agríc. PE. 12: 2257-2262.

Munné-Bosch, S., G. Queval and C. H. Foyer. 2013. The impact of global change factors on redox signaling underpinning stress tolerance. Plant Physiol. 161: 5-19.

Nawaz, F., M. Y. Ashraf, R. Ahmad and E. A. Waraich. 2013. Selenium (Se) seed priming induced growth and biochemical changes in wheat under water deficit conditions. Biol. Trace Elem. Res. 151(2): 284-293.

Nawaz, F., M. Y. Ashraf, R. Ahmad, E. A. Waraich and R. N. Shabbir 2014. Selenium (Se) regulates seedling growth in wheat under drought stress. Adv. Chem. 2014: Article ID: 143567, 7. DOI:10.1155/2014/143567.

Padayatti, S. J., R. Daruwala, Y. Wang, P. K. Eck, J. Song, W. S. Koh and M. Levine. 2001. Vitamin C: From molecular actions to optimum intake. In: Cadenas, E. and L. Packer, (Eds.), Handbook of Antioxidants, $2^{\text {nd }}$ ed. CRC Press, Washington, DC, USA. Pp. 117-145.

R Core Team. 2015. R: A Language and Environment for Statistical Computing. R Foundation for Statistical Computing. Vienna, Austria. Available from: https://www.R-project.org. [Last accessed on 2015 Dec 12].

Ramírez, H., C. E. Rivera-Cruz, A. Benavides-Mendoza, V. RobledoTorres and G. Reyna-Sustaita. 2010. Prohexadione-Ca, an alternative in the production of husk-tomato (Physalis ixocarpa Brot.) Rev. Chapingo Ser. Hortic. 16: 139-146.

Ramos, S. J., V. Faquin, L. R. G. Guilherme, E. M. Castro, F. W. Ávila, G. S. Carvalho, C. E. A. Bartos and C. Oliveira. 2010. Selenium biofortification and antioxidant activity in lettuce plants fed with selenate and selenite. Plant Soil Environ. 56: 584-588.

Rayman, M. P. 2008. Food-chain selenium and human health: Emphasis on intake. Br. J. Nutr. 100: 254-268.

Steiner, A. A. 1961. A universal method for preparing nutrient solutions of a certain desired composition. Plant Soil. 15: 134-154

Terry, N., A. M. Zayed, M. P. De Souza and A. S. Tarun. 2000 Selenium in higher plants. Ann. Rev. Plant Physiol. 51: 401-432.

Xu, J., S. Zhu, F. Yang, L. Cheng, Y. Hu, G. Pan and Q. Hu. 2003. The influence of selenium on the antioxidant activity of green tea. J. Sci. Food Agric. 83: 451-455.

Xue T., H. Hartikainen and V. Piironen. 2001. Antioxidative and growth-promoting effect of selenium on senescing lettuce. Plant Soil. 237: 55-61.

Zhao, X. Q., N. Mitani, N. Yamaji, R. F. Shen and J. F. Ma. 2010 Involvement of silicon influx transporter OsNIP2;1 in selenite uptake in rice. Plant Physiol. 153: 1871-1877. 